\title{
ПСИХОКОРЕКЦІЯ МОТИВАЦІЇ ДІТЕЙ ІЗ КОГНІТИВНИМИ ПОРУШЕННЯМИ
}

Леся Прохоренко, Інститут спеціальної педагогіки Національної академії педагогічних наук України, м. Київ, Україна

Зроблено спробу розкрити питання навчальної мотивації дітей як засобу досягнення результативності навчально-виховного процесу.

Ефективність розгортання навчально-виховного процесу має досягатися шляхом формування внутрішньої мотивації навчання вже з молодшого шкільного віку. Особливого значення набувають при цьому пізнавальні мотиви, оскільки забезпечують розширення меж розумового потенціалу підростаючої особистості, збагачення теоретичних знань практичним досвідом, сприяють розвитку волі учнів, виробленню вмінь самостійно ставити проміжні та кінцеві завдання, планувати свою діяльність, прогнозувати можливі результати.

Зважаючи на велику кількість різноманітних підходів до розкриття специфіки формування мотивації навчання в дітей 3 когнітивними порушеннями, важливо відзначити, що на сучасному етапі в педагогічній теорії і практиці недостатньо обумовлюється успішність пізнавальної діяльності таких учнів особистісно значущими чинниками в організації навчального процесу. Тому, проблема впливу на успішність навчання цих учнів їх соціального оточення, готовності до отримання нових знань, особливостей взаємодії учасників навчально-виховного процесу потребує більш ґрунтовного вивчення.

Ключові слова: мотивація досягнення, мотиваційна оцінка, проблемна ситуація, ситуація успіху, діти з когнітивними порушеннями.

Леся Прохоренко, Институт специальной педагогики и психологии имени Николая Ярмаченко Национальной академии педагогических наук Украины, г. Киев, Украина

Психокоррекция мотивации детей с когнитивными нарушениями

Осуществлена попытка раскрыть вопросы учебной мотивации детей как средства достижения результативности учебно-воспитательного процесса.

Эффрективность развертывания учебно-воспитательного процесса должно достигаться путем формирования внутренней мотивации учения уже с младшего школьного возраста. Особое значение приобретают при этом познавательные мотивы, поскольку обеспечивают расширение границ умственного потенциала подрастающей личности, применение теоретических знаний практически, способствует выработке умений самостоятельно ставить промежуточные и конечные цели, планировать свою деятельность, прогнозировать возможные результаты.

Несмотря на большое количество разнообразных подходов к раскрытию специфики формирования мотивации учения у детей с когнитивными нарушениями, важно отметить, что на современном этапе в педагогической теории и практике недостаточно объясняется успешность познавательной деятельности таких учащихся личностно значимыми фракторами (C) Прохоренко Л., 2019 
в организации учебного процесса. Поэтому, проблема влияния на успешность обучения этих школьников их социального окружения, готовности к получению новых знаний, особенностей взаимодействия участников учебно-воспитательного процесса требует более тщательного изучения.

Ключевые слова: мотивация достижения, мотивационная оценка, проблемная ситуация, ситуация успеха, дети с когнитивными нарушениями.

Lesia Prokopenko, Mykola Yarmachenko Institute of special education and psychology of the National Academy of Educational Sciences of Ukraine

\section{Psychocorrection of motivation of children with cognitive disorder}

The article attempts to reveal the problem of educational motivation of children with cognitive impairments as a means of achieving the effectiveness of the educational process.

The effectiveness of the deployment of the educational process should be achieved through the formation of internal motivation of education from the junior school age. Of particular importance are the cognitive motives, as they provide the expansion of the limits of the intellectual potential of the growing personality, enriching theoretical knowledge with practical experience, promote the development of students' will, develop skills to independently set intermediate and final goals, plan their activities, predict possible outcomes.

In view of the large number of diverse approaches to the disclosure of the specifics of the formation of motivation for teaching in primary school children, it is important to note that at present, pedagogical theory and practice do not sufficiently determine the success of cognitive activity of students by personally significant factors in the organization of the educational process. Need more thorough study of the impact on the success of training younger students of their social environment, readiness to acquire new knowledge, features of the interaction of participants in the educational process.

Keywords: motivation of achievement, motivational estimation, problem situation, situation of success, children with cognitive impairments.

$\mathrm{H}^{3}$ а сучасному етапі система освіти в Україні зазнає кардинальних змін. Реформування освіти зорієнтовано на імплементацію європейських цінностей, 3-поміж яких насамперед є дотримання прав людини, рівність усіх громадян, зокрема рівні можливості для людей з обмеженими можливостями, можливість реалізації особистої свободи та самореалізації кожного індивіда. Ці положення закріплено в Законі «Про освіту», у якому, з- поміж іншого, значна увага приділяється забезпеченню реалізації права на освіту особами 3 особливими потребами. Уперше в новітній історії нашої країни українську школу зорієнтовано на формування життєвої компетентності та самостійності особистості кожної дитини, незалежно від особливостей їі психофізичного розвитку.

За міжнародною класифікацією хвороб 10-го перегляду до загальних ознак порушення когнітивного розвитку (F06.7) відносять різноманітні відносно легкі аномалії розвитку, що характеризуються незрілістю емоційно-вольових функцій, уповільненим темпом психічного розвитку, негрубими порушенням пізнавальної діяльності, особистісною незрілістю, які за структурою та якіс- 
ними показниками відрізняються від розумової відсталості і мають тенденцію до компенсації та розвитку. Організація навчання дітей із порушеннями когнітивного розвитку залежить від того, наскільки їхній актуальний розвиток наближається до рівня готовності засвоювати шкільну програму, прийняти позицію учня.

Як відомо, навчальна діяльність дитини формується на підгрунті поступового переходу від домінування неусвідомлених мотиваційних процесів до домінування усвідомлених мотивів діяльності.

У підгрунті мотивації учнів із порушеннями когнітивного розвитку полягають потреби, які не спрямовують активність дітей на досягнення поставленої мети, водночас, внаслідок церебральних чи системних причин, процес мотивації у таких дітей протікає з певними особливостями і ускладненнями. Тому метою статті є висвітлення результатів дослідження формування якісних мотиваційних процесів, від яких залежить продуктивність пізнавальної діяльності, що сприяє підвищенню рівня реалізації можливостей дитини у вирішенні поставлених перед нею завдань. Реалізація цих завдань спонукала визначення критеріїв мотивації досягнення до яких увійшли: співвіднесення заданих умов з уявним очікуваним результатом; вибір альтернативного варіанту дій; утворення наміру; контроль над задумом; оцінка мотиваційних процесів після завершення дії (оцінка міри досягнення поставленої мети). Експериментальна програма з формування мотивації досягнення учнів передбачала адаптацію/модифікацію таких методик як: «Комунікативна атака», «Дискусія», «Створення проблемної ситуації», «Створення ситуації успіху» (H. Eysenck, D. McClelland, Д. Ельконіна, В. Давидова, Ю. Тамберг, К. Поппер). Кількісний і якісний аналіз результатів дав змогу зробити висновок - розроблена психокорекційна програма з формування мотивації навчальних досягнень сприяла якісним зрушенням у розвитку всіх компонентів саморегуляції учнів з порушеннями когнітивного розвитку.

Вивчення мотивації, ï впливу на розвиток здатності до навчальної діяльності дітей із порушеннями когнітивного розвитку є однією із складних і недостатньо вивчених проблем в психолого-педагогічній науці. Якщо у середині IX ст. предмет, межі й специфіка психології мотивації досліджувалися в контексті поведінкової психології, то вже у XX ст. сфера дослідження мотивації набуває ширших меж і фактично розподіляється між соціально-когнітивною психологією (А. Bandura, G. Kelly, B. Skinner, C. Hull, J. Piage, 3. Фройд), психологією особистості (Р. Бернс, Л. Виготський, Г. Костюк, Б. Ломов ) та психологією діяльності (В. Давидов, В. Зінченко, О. Леонтьев, J. Atkinson, W. Kohler, E. Lowell). Ідеться про взаємодію мотиваційних детермінантів, які в здебільшого пов'язують з ситуативними чинниками поведінки, а почасти 3 індивідуальними особливостями людини, інакше - про «взаємодію особистості і ситуації». У сучасній психології, мотивація розглядається як результат такої взаємодії вплив мотиваційних чинників на постановку мети діяльності задля отримання

«ОСОБЛИВА ДИТИНА: навчання і виховання», № 2, 2019 77 
ефективних результатів. Прикладом може слугувати те, як один учень виявляє завзятість у навчанні, не лише в школі, а й у позашкільній діяльністі, тоді як інший - демотивований навіть у шкільній ситуації, не виявляє бажання до здобуття знань.

Такі індивідуальні відмінності людей можна простежити у різних сферах дійсності, що свідчить про особистісну їх своєрідність у сенсі розмаїтих ціннісних диспозицій, які виявляються як у підсиленні, так і у послабленні спонукання до певних дії в кожній конкретній ситуації або й у повній заміні іх на інші, котрі не потребують якихось зусиль. Ціннісні диспозиції, що спрямовують дію людини, а також ієрархія мотиваційних установок і $є$ тими критеріями, котрі визначають індивідуальні відмінності й те, чому за одних і тих же обставин одна людина чинить інакше, ніж інша.

В ієрархії мотивації, кожен з мотивів відрізняється певним класом цілей, які визначають зміст діяльності і які можна узагальнено назвати як «досягнення», «надання допомоги», «винагорода», «уникнення труднощів» тощо. Кожен мотив у своєму підгрунті пов’язаний з відповідним йому класом цілей, наприклад, мотив досягнення пов'язується з такими цілями як зіставлення з критеріями успішності (D. McClelland, 2010). Ефективно дії, що виконується, буде досягнуто тоді, коли ймовірними будуть результати, які бажані для індивіда, тобто виконання будь-якої діяльності супроводжується вірогідністю запровадження задуму, що має певну цінність для людини або гарантує іï здійснення.

Вирішальне значення у цьому сенсі мають дві величини: цінність задуму для людини й імовірність, яким чином цей задум буде досягнуто. Якщо з'ясовано вибір дії з кількох можливих варіантів і вибудувано стратегію для прийняття оптимального рішення, то збільшується ймовірність того, що дія для досягнення задуму буде успішною.

Навчальна діяльність, про що вже йшлося, це діяльність спрямована на оволодіння узагальненими способами дії у сфері наукових понять, то ж вона має спонукатися адекватними мотивами. Такими можуть бути лише мотиви, безпосередньо пов'язані з їі змістом, тобто мотиви досягнення, інакше кажучи, ті мотиви, які забезпечують власне зростання, самовдосконалення. Відомо, що знання, уміння і навички діти отримують не тільки в школі і не лише в результаті навчальної діяльності, а й під час самостійного читання книжок, журналів, 3 радіо і телепередач, перегляду фільмів і відвідуванні театру, з розповідей батьків і однолітків, а також в ігровій та трудової діяльності. Навчальна діяльність обумовлюється системою різноманітних мотивів: основними (внутрішніми - навчально-пізнавальними), які спрямовують діяльність учнів на засвоєння теоретичних знань і другорядними (зовнішніми) - отримання хорошої оцінки, підвищення свого престижу, уникнення неприємностей тощо (A. Bandura (1991); D. McClelland (2010); A. Elliot (2003); Є. Ільїн (2003); Х. Хекхаузен (2003). 
Отже, правомірним є питання про те, які мотиви, яким способом і за яких умов сприятимуть засвоєнню дитиною у школі наукових понять.

На думку багатьох учених, успішність та продуктивність навчальної діяльності дітей залежить саме від домінування мотиваційних процесів досягнення, які забезпечують активність особистості на всіх етапах розгортання діяльності, визначають спосіб досягнення поставленої мети, іiі послідовність та реалізацію, сприяють встановленню співвідношення запланованого, передбачуваного і досягнутого результату відповідно до мети (А. Леонтьев (1971); А. Маслоу (2003); М. Неймарк (2011); Е. Тєлєгіна (2003) та ін.).

Утім, як було з'ясовано, у навчальній діяльності учнів з порушеннями когнітивного розвитку найбільш поширеним виявляється мотив уникнення невдачі, який орієнтований не на рівень домагань, а на оцінку дорослого, уникнення покарання, бажання похвали, що зумовлюе низький рівень навчальних мотивів, тому перехід від мотивації до дії відбувається з певними особливостями.

У зв'язку з цим значної актуальності набуває питання формування мотивації навчання учнів із когнітивними порушеннями, розроблення програми психокорекції мотиваційних процесів досягнення.

Отримані дані слугували підгрунтям для розроблення психокорекційної програми формування мотивації досягнення, у якій розвиток мотивації досягнення розглядався не лише як сукупність певних спонукальних засобів щодо власних дій, а й як процес розгортання мотивації дитини від початку до ї завершення.

Програма психокорекції містила серію діагностично-розвивальних та прогностичних завдань. Діагностично-розвивальні завдання були спрямовані на розвиток мотивації навчання та формування інтересу до навчальної діяльності. Прогностичні - передбачали підвищення рівня мотивації досягнення на основі потенційних можливостей дитини. Проведення корекційно-розвивальної роботи з розвитку мотивації передбачало роботу з формування внутрішніх дій переходу від мотивації до дії, через мотиваційний вибір, утворення наміру та ініціацію дії.

Система діагностично-розвивальних завдань містила комплекс методів, метою яких $є$ цілеспрямоване формування мотивації досягнення на початку роботи (готовність до роботи), мотивації в процесі виконання роботи (включеність, підтримка інтересу, уважність тощо), мотивації завершення.

Одним із таких методів, що були використані для формування мотивації досягнення, - комунікативна атака (Ю. Тамберг). Цей метод грунтується на активізації емоційної сфери учня (виклик подиву, захоплення через використання ефекту новизни, несподіваності). Стратегія цього методу передбачала:

а) міжпредметне ув'язування навчального матеріалу, постановку широких завдань, аби учні розуміли його;

б) підтримку відповідальності дітей за розв'язання;

«ОСОБЛИВА ДИТИНА: навчання і виховання», № 2, 2019 79 
в) створення автентичних завдань, складність яких відповідала б здібностям учнів;

г) акцентування на рефлексію щодо вивченого матеріалу.

Метод дискусії (К. Поппер), - конструктивний і організований обмін поглядами з конкретної проблеми. Під час дискусії учні набувають нових знань, навчаються висловлювати власну думку, обгрунтовувати та відстоювати своє бачення, що позитивно впливає на розвиток внутрішньої мотивації - учні відчувають себе активними і компетентними суб'єктами навчального процесу.

Метод «створення проблемної ситуації (D. McClelland; Д. Ельконін, В. Давидов). Створювалася ситуація утруднення, що змушувала учнів переглянути суть завдання, спосіб розв'язування, зіставити наявні знання 3 новими умовами i зробити висновок. Тобто, перший крок - розв'язування такого завдання спонукає учня до помилки, а наступний - до обгрунтування цієї помилки.

Метод «створення ситуації успіху» (H. Eysenck, D. McClelland), передбачав продукування мотиву досягнення засобами введення у спеціально змодельовані ситуації, поєднання умов які різною мірою актуалізували цей мотив.

У процесі розв'язання діагностичних завдань було з'ясовано, що учні з мотивацією досягнення виконуючи завдання намагаються правильно формулювати мету, планувати дії для реалізації конкретного результату, аналізувати реальність поставленої мети і отриманого підсумку, передбачати наслідки дій, водночас, було виявлено, що у таких дітей значно вищий рівень самооцінки і навчальних мотивів. Водночас учні, які мотивовані на уникнення невдач, не ставлять перед собою цілі, що вимагають зусиль для їх досягнення, вибирають легкі завдання, які не потребують особливих пізнавальних затрат, шукають причини відмови від складних завдань, відповідно виявляють мотивацію уникнення невдачі. Мотиваційні процеси досягнення, такі як вибір належного варіанту дій, пов'язаного 3 уявним результатом діяльності, утворення наміру, потреба переборювати труднощі для досягнення поставленої мети, а також мотиваційне оцінювання власних результатів діяльності, у цих учнів не сформовані (Л. Прохоренко, 2015; Л. Прохоренко, К. Бужинецька, 2018).

Отже, перше завдання психокорекційної програми передбачало формування взаємозв'язку між внутрішніми і зовнішніми мотивами на різних етапах уроку. 3 цією метою було використано метод «комунікативна атака». Під час навчання, дітей зацікавлювали невідомими фактами, обіцянкою чогось несподіваного, аби вони чекали на кульмінацію. Методичними прийомами було обрано: ефектну цитату; незвичайну дію; розповідь казки, оповідання, притчі; цікаве запитання; особисте зацікавлення (інформація, яка близько пов’язана з інтересами учнів) тощо.

За результатами методики було з'ясовано, що засобами заохочення, стимуляції, несподіванки актуалізувалися мотиви досягнення, що викликало у дітей 
прояв вольових зусиль для досягнення мети (у 55\% молодших підлітків зростала внутрішня стимуляція до виконання завдання, навмисна зміна мотивації, яка поєднувалася з мотивом отримання високої оцінки своєї роботи, що зорієнтовувало дітей на якість і результативність навчальних дій, тобто спостерігалися мотиви досягнення. Утім, у 45\% дітей, без стимуляції зовні, інтерес до роботи зникав і переважало бажання залишити допрацювати завдання «на потім» або одержати допомогу дорослого, що свідчить про домінування мотиву уникнення труднощів над навчальним).

Поряд з цим, для підсилення мотиваційних процесів досягнення (співвіднесення заданих умов з уявним очікуваним результатом; вибір альтернативного варіанту дій; утворення наміру; контроль над задумом; оцінка міри досягнення поставленої мети) використовувався метод дискусіі: після виконання завдання, разом з дорослим, учні аналізували висновок стосовно поставленої проблеми та цілісний процес розв'язання. Наприкінці, оцінювали привабливість запланованого результату дій, аналізували ті знання і вміння, які були необхідні для його реалізації. Водночас, дискутували щодо цінностей отриманого результату для кожного з учнів, аналізували їхні зусилля і досягнення. Отримані дані засвідчили ефективність таких дискусій. Так, зокрема $62,5 \%$ учнів почали віддавати перевагу ускладненим завданням (або цікавим незнайомим завданням) над завданнями знайомими і легкими, що підтверджує формування в них навчального мотиву, прояв мотивації досягнення. 37,5\% дітей проявляли інтерес до легших завдань, а в складніших умовах, працювали самостійно лише тоді, коли повідомлялося, що робота оцінена не буде. Складні завдання рідко викликали у них пізнавальний інтерес, при цьому щоб довести розпочату роботу до логічного завершення потребували певної стимуляції, допомоги дорослого.

Іншою складовою функціональної структури мотивації досягнення є виділення учнем мети вибраної дії, що дає змогу визначити проміжні цілі, необхідні для досягнення основної мети та оцінити ці мотиваційні процеси після завершення дії. 3 метою формування вказаних мотиваційних процесів було використано методи «створення проблемної ситуації та «ситуації успіху».

Проблемні ситуації передбачали виконання завдання, які не можна виконати через відсутність для цього наявних знань і вмінь. Наприклад, учням пропонувалося виконати завдання, які містили так звані, «пастки». Мета таких завдань полягала в осмисленні дитиною: чому не можна вирішити це завдання i, на основі зроблених висновків, сформулювати запитання, яке дасть змогу знайти інформацію для правильного розв'язання. Водночас, аби дати відповідь на поставлене запитання необхідно розглянути умову завдання, встановити співвідношення між умовою і вимогами, визначити спосіб реалізації, переглянути задум і визначити напрями реалізації, тобто задіювалися всі мотиваційні процеси. «Завданняпастки» були різних типів: пов'язані із зайвими або частиною відсутніх даних;

«ОСОБЛИВА ДИТИНА: навчання і виховання», № 2, 2019 81 
3 неправильною вихідною умовою; завдання, у яких навмисно допущені помилки. Під час розв’язування таких завдань, дітям спочатку пропонувалося «позбутися пастки», потім придумати своє завдання 3 «пасткою» мообмінювання «пастками», їх пояснення без допомоги дорослого, перетворення і розв’язування.

Після проведення серії «завдань-пасток» у більшості учнів (60\% дітей) засвідчено домінування мотивації досягнення під час розв'язання навчальних завдань як у знайомих умовах, так і у змінених. Учні значно швидше залучалися у навчальну ситуацію, намагалися правильно зорієнтуватися у вимогах завдання, визначити правильний спосіб виконання, наприкінці виконання співвідносили отриманий результат з поставленою метою.

Для «ситуації успіху» були змодельовано дві ситуації: ситуація, орієнтована на досягнення (успіху) і «нейтральна ситуація», у якій не акцентувалося на мотивації досягнення. На кожному занятті, дітям, що були охоплені дослідженням пред'являли різні тестові завдання, які були доступні для розуміння дітям 3 когнітивними порушеннями та, методики на кшталт, розробки D. McClelland, картинки, але із зображенням навчальних ситуацій, за якими діти складали сюжет на свій розсуд.

У «нейтральній ситуації» учні складали «маленьку історійку» за сюжетом пред'явленої картинки. Словосполучення «маленька історійка» навмисно вживалося зі зменшувальним суфіксом, щоб зняти асоціації дітей з розповіддю як літературною формою i, тим самим, знизити значущість завдання, послабити внутрішню напруженість учнів, яка виникає у них при розв'язанні проблемних ситуацій. У «ситуації успіху» учнів орієнтували на досягнення, підкреслювали значення завдань, пояснювали, що вони будуть оцінені і закликали дітей намагатися виконати завдання якомога краще. Після виконання завдань, охоплені досліджуванням учні, могли порівняти свої результати з відповідями, які їм пропонувалися. Дітям також пропонувалося три серії тестових завдань, вимоги першої серії були не складними, тому кожен учень міг досягти «успіху», вимоги двох інших - поступово вскладнювалися.

Отримані дані за цією методикою засвідчили позитивні зрушення в мотивації досягнення дітей. Так, вмотивованими на досягнення виявилося у першій ситуації - 77,5\% учнів, у другій - 70\% і у третій $-67,5 \%$.

Інтерпретуючи результати можна стверджувати, що після використання методик, ефективність виконання завдань у навчальних ситуаціях була вищою: діти виявляли мотиви досягнення, які опосередковувалися такими цілями як «хочу досягти хорошого результату», «мені цікаво це знати», «хочу знати більше», «хочу отримати гарну оцінку». Поряд з цим спостерігали значно рідші звертання по допомогу вчителя, бажання перевірити отриманий результат, оцінити узгодженість прогнозованої мети та отриманих результатів. Водночас, близько 
$30 \%$ учнів потребували допомоги дорослого, самостійно не могли спланувати завдання та реалізувати його втілення. Утім, учнів, які виявилися б повністю демотивованими до навчання виявлено не було.

Висновки. Упроваджена у практику програма психокорекції мотиваційних процесів досягнень учнів з порушеннями когнітивного розвитку засвідчила, що формування мотивації досягнення, насамперед, залежить від створення спеціальних умов щодо підтримки продуктивних форм зовнішньої мотивації, інтересу до навчання, позитивного ставлення до змісту та процесу навчальної діяльності, за яких і відбувається вправляння у якісному виконанні навчальних завдань, поліпшенні результатів навчання. Поряд з цим, використання різноманітних методичних прийомів, таких як комунікативна атака, використання проблемної ситуації в навчанні, закріплення позитивного враження, створення ситуації успіху, розв'язання тестових завдань тощо, позитивно відображаються на формуванні мотивації досягнення.

Тлумачення отриманих даних дає підстави стверджувати, що після проведення психокорекційної програми учні з порушеннями когнітивного розвитку виявляють здебільшого позитивну динаміку мотивації начальних досягнень що засвідчує їі ефективність.

У ході корекційно-розвивального впливу на мотивацію досягнення, в учнів спостерігається розвиток навчальних мотивів (у $\approx 60 \%)$ з помітним зниженням зовнішніх. Водночас, треба зазначити, що поряд з навчальними мотивами, у дітей зросла мотивація, пов'язана із задоволенням від подолання труднощів, отримання позитивного результату під час розв'язування проблемних завдань, прагнення до адекватної самооцінки.

Після проведення спеціальних занять, які передбачали розв'язування проблемних завдань, в учнів простежується спрямованість на мотивацію успіху, а саме: під час визначення мета виконання завдання, діти відштовхувалися від засвоєних досягнень, аналізували варіанти способів дій, визначали раціональний і переходили до його виконання, тобто ставили реальну мету досягнення результату. Так, при розв'язуванні навчальних завдань на уроках, 67\% дітей, які піддавалися впливу психокорекційної програми, спочатку уважно аналізували умову, потім пояснювали, які способи можна використати для того, щоб знайти результат і, лише визначившись з варіантом дій, переходили до виконання, хоча на перших заняттях вони одразу починали розв'язувати завдання, зважаючи лише на попередній спосіб дій. Тож, можна стверджувати, що учнів з'явилася виражена внутрішня мотивація на досягнення, спостерігається наявність усвідомленого наміру, переважає орієнтація на зміст і процес начальної діяльності.

Ефективною виявилася й робота, яка передбачала підвищення мотивації у дітей засобами створення ситуацій успіху, з метою формування «прагнення до завершення», тобто, довести процес мотивації до мотиваційної оцінки діяль-

«ОСОБЛИВА ДИТИНА: навчання і виховання», № 2, 2019 83 
ності. У результаті, під час виконання самостійних робіт було встановлено, що такі учні (42,5\%) після утворення наміру були орієнтовані на побудову плану і реалізацію задуму в дію, що вказує на розгорнутий акт рішення, а не на елементарне здійснення однієї з альтернативних дій. Ускладнення експериментальних завдань у ситуаціях успіху, створення ситуацій повернення до перерваної дії, дало змогу сформувати в учнів мотиваційні процеси «після завершення дії», які містять мотиваційну оцінку, визначають наскільки досягнута намічена мета і якою мірою утворений намір реалізовано, фактично спостерігається «контроль над діями». У більшості учнів (52,5\%) відслідковується два типи «контролю над діями», перший - як контроль над задумом після утворення наміру і до початку дії, а другий - у процесі ініціації і реалізації дії, у вигляді контролю за ходом дії, що дає змогу учням зробити висновок щодо повноти впровадження задуму.

Отже, можна стверджувати, що в учнів, які піддавалися психокорекційному впливу щодо формування мотивації досягнення спостерігається заміщення домінування зовнішніх мотивів на внутрішні, що сприяє розвитку когнітивних компонентів кінцевої мети. Принципово важливим $є$ й те, що ці мотиви охоплюють визначення проміжних цілей, уявлення про послідовність дій, побудову плану дій, водночас, посилюють мотиви досягнення і інтерес до власного навчання.

Так, у результаті цілеспрямованої корекційно-розвивальної роботи з формування навчальної мотивації, у більшості учнів експериментальної групи відбулися якісні зміни у мотиваційній сфері, що засвідчує ефективність корекційнорозвивальної програми. Водночас, у окремих дітей хоча і відбулися певні зміни у мотиваційній структурі, утім, не такі вагомі, що підтверджує думку про необхідність продовження корекційно-розвивального впливу на мотивацію досягнення цих учнів.

\section{ЛITEPATУPA}

1. Маслоу А. Г. Мотивация и личность / А. Г. Маслоу. - СПб. : Питер, 2003. - 352 с.

2. Неймарк М. С. Изучение мотивации поведения детей / М. С. Неймарк, В. Э. Идиновский. - М. : Педагогика, 2011. - 384 с.

3. Прохоренко Л. І. Бужинецька К. Б. Психологічні аспекти пізнавальної мотивації дітей з порушеннями когнітивного розвитку // Тези доповідей Міжнародної науково-практична конференція «Інклюзивне навчання в Новій українській школі» (26-27 березня 2018 року). - Теребовля : Інтерсервіс, 2018. - С. 184-187.

4. Прохоренко Л. I. Експериментальна модель формування саморегуляції навчальної діяльності школярів із затримкою психічного розвитку / Л.І.Прохоренко // Вісник одеського національного університету. - 2017. - № 45 - - С. 61-70.

5. Сак T. B. Індивідуалізація навчання учнів з особливими освітніми потребами в інклюзивному класі / Т. В. Сак // Особлива дитина: навчання і виховання. - 2014. - №4 (69). C. 3-6.

6. Хекхаузен Х. Мотивация и деятельность / Х. Хекхаузен. - М. : Смысл, 2003. - 860 с. 
7. Bandura A. Social cognitive theory of self-regulation / A. Bandura // Organizational Behavior and Human Decision Processes. 1991(a). - V. 50, P. 248-287.

8. David McClelland's Research into Achievement Motivation / D. McClelland's // Team Building Training and Development. - 2010.- Web. 03 Nov.

\section{REFERENCES (TRANSLATED AND TRANSLITERATED)}

1. Maslou A.G. (2003). Motivatsiia i lichnost [Motivation and Personality]. Piter: SPb [In Rosiia].

2. Neimark M.S. (2011). Izuchenie motivatsii povedeniia detei [Studies in Motivation of Children's Behavior]. Moskva: Pedagogika [In Rosiia].

3. Prohorenko L. I., Buzhynetska K. B. (2018). Psykholohichni aspekty piznavalnoi motyvatsii ditei z porushenniamy kohnitivnoho rozvitku [The Psychological Aspects of Learning Motivation of Children with Cognitive Development Disorders]. Proceedings from MIIM; MizhnarodnA naukovo-praktychna konferentsiia «Inkliuzyzne navchannia v Novii ukrainskii shkoli» (P. 184-187). Terebovlia : Interservis [In Ukrainian].

4. Prohorenko L. I. (2017). Eksperymentalna model formuvannia samoreguliatsii navchalnoi diialnosti shkoliariv iz zatrymkoiu psykhichnoho rozvitku [An Experimental Model of Developing Self-regulation of Learning Activity of Schoolchildren with Developmental Delays]. Visnik odeskogo natsionalnogo universytetu, 45, 61-70.

5. Sak T.V. (2014). Individualazatsia navchanniia uchniv z osoblivimy osvitnimy potrebamy $\mathrm{v}$ inkliuzivnomu klasi [The Individualization of Learning of Students with Special Educational Needs in the Inclusive Classroom] Osoblyva dytyna: navchannia i vykhovannia, 4(69), 3-6.

6. Khekkhauzen Kh. (2003). Motyvatsiia y deiatelnost [Motivation and Activity]. Moskva : Smysl, [In Rosiia].

7. Bandura A. Social cognitive theory of self-regulation / A. Bandura // Organizational Behavior and Human Decision Processes. 1991(a). - V. 50, P. 248-287.

8. David McClelland's Research into Achievement Motivation / D. McClelland's // Team Building Training and Development. - 2010.- Web. 03 Nov. 